\title{
Control of Penaeid Acute Viremia (PAV) in Penaeus japonicus: Selection of Eggs Based on the PCR Detection of the Causative Virus (PRDV) from Receptaculum Seminis of Spawned Broodstock
}

\author{
Keiichi Mushiake ${ }^{1 *}$, Ken Shimizu ${ }^{1}$, Jun Satoh ${ }^{2}$, Koh-ichiro Mori ${ }^{1}$, Misao Arimoto ${ }^{1}$, \\ Shin-ichi Ohsumi ${ }^{1}$ and Keinosuke Imaizumi ${ }^{2}$ \\ ${ }^{1}$ Kamiura Station of Japan Sea-Farming Association, Kamiura, Minamiamabe, \\ Oita 879-2602, Japan \\ ${ }^{2}$ Shibushi Station of Japan Sea-Farming Association, Shibushi, Soo, \\ Kagoshima 899-7101, Japan
}

(Received August 20, 1999)

\begin{abstract}
In order to prevent penaeid acute viremia (PAV) in seed production of kuruma prawn Penaeus japonicus, the presence of penaeid rod-shaped DNA virus (PRDV) in the ovary and receptaculum seminis was examined by polymerase chain reaction (PCR). The detection rate of PRDV was always higher in the receptaculum seminis than in the ovary. The prevalence of the virus in the receptaculum seminis became higher after spawning, especially in the spawners that required a longer period to induce spawning. PAV occurred in postlarvae cultured at Kamiura Station of Japan Sea-Farming Association in 1997 when segregation of spawners was made based on the results of PRDV detection from ovaries before spawning, whereas the disease did not occur in 1998 or 1999 when segregation of eggs was performed according to the result of virus detection from the receptaculum seminis after spawning. These results indicate that the selection of eggs should be done in the hatchery based on the results of PCR detection from receptaculum seminis of spawners after spawning.
\end{abstract}

Key words: PAV, WSS, PRDV, Penaeus japonicus, broodstock, receptaculum seminis, baculovirus

Serious mortalities due to a viral disease among populations of cultured kuruma prawn Penaeus japonicus have occurred in western Japan since 1993 (Nakano et al., 1994), and the disease has become a significant obstacle in prawn culture. In Japan, this viral disease has been called penaeid acute viremia (PAV), and the causative virus was named as penaeid rodshaped DNA virus (PRDV) (Inouye et al., 1996). PAV, equivalent of white spot syndrome (WSS) in south-east Asian countries (Takahashi et al., 1996; Lo et al., 1996), has become the most serious problem not only in shrimp farming industry but also in shrimp hatcheries for seafarming (Momoyama et al., 1997; Satoh et al., 1999). WSS has been reported in cultured kuruma prawn, black

\footnotetext{
* Corresponding author
}

tiger shrimp $P$. monodon, redtail shrimp $P$. penicillatus and Chinese prawn $P$. chinensis (Chou et al., 1995; Wongteerasupaya et al., 1995; Peng et al., 1995; Lightner, 1996).

The major infection route of PRDV in grow-out ponds is considered to be by horizontal transmission from diseased prawns to healthy ones (Nakano et al., 1994). On the other hand, in seed production facilities PAV is shown to be transmitted vertically from brooders to their offsprings (Maeda et al., 1998; Satoh et al., 1999). This suggests the importance of eliminating PRDV-positive spawners in seed production. In 1997, segregation of PCR-positive spawners was made based on the results of PRDV detection from ovaries before spawning according to our previous results (Mushiake et al., 1998). However, PAV occurred in postlarvae, 
which were obtained from brooders caught between July and August. Thus, it was found that the selection of spawners based on the detection of PRDV from ovaries before spawning was insufficient as a control measure of PAV. Therefore, a more appropriate organ for the PCR detection of the virus in spawners should be searched for more reliable selection of the spawners.

In the present study, we examined the receptaculum seminis, which preserves sperm obtained from males through copulation located on the ventral side at the center of the body in females, as well as the ovaries for the detection of PRDV before and after spawning. As a result, it was found that the vertical transmission of the virus can be effectively prevented by eliminating the contaminated eggs based on the PCR detection of PRDV from receptaculum seminis after spawning.

\section{Materials and Methods}

\section{Broodstock and spawning}

Adult kuruma prawn, which were caught in coastal waters off eastern Kyushu, were purchased from dealers and used as spawners between April and August in 1997, or between March and July in 1998 and 1999.

In 1997 , the ovaries $(0.1 \mathrm{~g})$ of all females $(1,413$ in total) were sampled individually by using a disposable syringe ( $3.0 \mathrm{~mL}$; needle $19 \mathrm{G}$ ) and the stages of ovarian maturation were examined by biopsy (Miyajima and Matsumoto, 1996) just after transport to the Kamiura Station, Oita Pref., of Japan Sea-Farming Association (JASFA). At the same time, the receptaculum seminis $(0.1 \mathrm{~g})$ was sampled from some spawners before spawning from June. After individual microscopic examination of ovary, the spawners which reached the final maturational stage (oocytes with cortical alveoli) were selected and stocked individually in $10 \mathrm{~L}$ tanks at $15-18^{\circ} \mathrm{C}$ for spawning suppression until the PCR examination of PRDV from ovaries was completed. Only spawners (969 in total) having PCR-negative ovaries were installed into a spawning tank $\left(25 \mathrm{~m}^{3}\right)$ at $23-27^{\circ} \mathrm{C}$ for induction of spawning.

In 1998 and 1999, a total of 1,212 and 715 kuruma prawns were purchased, respectively. After transport to the station, 10 to 15 individuals without biopsy were stocked separately in $0.5 \mathrm{~m}^{3}$ spawning tanks at $23-27^{\circ} \mathrm{C}$ for induction of spawning. At the same time, ovaries $(0.1 \mathrm{~g})$ and receptaculum seminis $(0.1 \mathrm{~g})$ were sampled from some spawners before spawning.

Each spawning experiment was continued for 3 days in every year. After spawning in the first day, spawners were divided into 3 groups according to spawning states by perspective observation of the ovary; complete spawning, partial spawning and no spawning groups. From the spawners of the first and second groups, both ovary and receptaculum seminis were sampled for the PRDV detection by PCR, whereas prawns with non-spawning were once again submitted to induction of spawning in the next day. The ovary and receptaculum seminis were sampled on the next day from the prawns with complete or partial spawnings, and the 3rd group was passed on to the next day. The same procedure was repeated in the 3rd day. From the prawns which did not spawn even in the 3rd day, both tissues were sampled on the 4th day. Based on the PCR results on the receptaculum seminis after spawning, the eggs from PCR-negative spawners were used in the following rearing experiments.

\section{Rearing and sampling of seedlings}

In 1997, the eggs just after obtained from PCRnegative brooders were disinfected with povidone-iodine (final concentration was $5 \mathrm{mg} / \mathrm{L}$ as active ingredient) for $5 \mathrm{~min}$, and stocked in rearing tanks $\left(100\right.$ or $\left.150 \mathrm{~m}^{3}\right)$ kept at temperature between 23 and $27^{\circ} \mathrm{C}$. In 1998 and 1999 , the eggs from every batch of spawners were disinfected as previous year and stocked in $0.2 \mathrm{~m}^{3}$ tanks until the PRDV detection was completed. And only eggs from PCR-negative spawners were stocked in rearing tanks $\left(100\right.$ or $\left.150 \mathrm{~m}^{3}\right)$.

During the rearing experiments in these 3 years, the larvae were fed Tetraselmis tetrathele, nauplii of Artemia salina and commercial formula feed, supplying sandfiltered and ozone-disinfected sea water maintained at $23^{\circ} \mathrm{C}$ or higher. Kuruma prawn seedlings were sampled at the nauplius, zoea, mysis and postlarval stages (P1: $1 \mathrm{mg}$ of average body weight, $\mathrm{P} 5: 1.5 \mathrm{mg}$, P10: $3 \mathrm{mg}$, P20: $12 \mathrm{mg}, \mathrm{P} 30: 30 \mathrm{mg}, \mathrm{P} 40: 100 \mathrm{mg}$ and P50: $200 \mathrm{mg}$ ). Each developmental stage: P1, P5, $\mathrm{P} 10, \mathrm{P} 20, \mathrm{P} 30, \mathrm{P} 40$ and $\mathrm{P} 50$ indicates $1,5,10,20,30$, 40 and 50 days post-metamorphosis, respectively, as usually termed in kuruma prawn seed production facilities in Japan.

\section{DNA extraction and detection of PRDV by PCR}

The sampled ovary and receptaculum seminis were homogenized and digested with ISOGEN (Japan Gene Company). The total DNA was extracted with chloroform and ethanol and two PRDV specific primer sets, P1/ P2 and P3/P4, were used as reported by Kimura et al. (1996). After 30 cycle amplification for each primer set at $93^{\circ} \mathrm{C}(60 \mathrm{~s}), 57^{\circ} \mathrm{C}(90 \mathrm{~s})$ and $72^{\circ} \mathrm{C}(60 \mathrm{~s})$, amplified products were analyzed by agarose gel electrophoresis. PRDV-infected $P$. japonicus was similarly processed as a positive control.

\section{Results}

\section{Detection of PRDV before and after spawning}

The prevalence of PRDV from ovary and receptaculum seminis of spawners before and after spawning from 1997 to 1999 are shown in Table 1. The total prevalence of PRDV from the ovaries of broodstock before 
Table 1. Prevalence of PRDV from ovary and receptaculum seminis of kuruma prawn spawners by nested PCR before and after spawning during 1997-1999

\begin{tabular}{|c|c|c|c|c|}
\hline \multirow{3}{*}{$\begin{array}{c}\text { Date of } \\
\text { purchase }\end{array}$} & \multicolumn{4}{|c|}{ Prevalence of PRDV (\%) } \\
\hline & \multicolumn{2}{|c|}{ Ovary } & \multicolumn{2}{|c|}{ Receptaculum seminis } \\
\hline & pre-spawning & post-spawning & pre-spawning & post-spawning \\
\hline '97. Apr. & $1.6(4 / 248)^{* 1}$ & $3.4(3 / 87)$ & $\mathrm{NE}^{* 2}$ & NE \\
\hline May & $0(0 / 81)$ & $0(0 / 40)$ & NE & NE \\
\hline Jun. & $0(0 / 108)$ & $0(0 / 37)$ & $0(0 / 38)$ & $2.3(2 / 86)$ \\
\hline Jul. & $0.7(2 / 297)$ & $4.0(4 / 101)$ & $8.6(6 / 70)$ & $39.2(83 / 212)$ \\
\hline Aug. & $1.3(3 / 240)$ & $10.0(10 / 100)$ & $5.7(2 / 35)$ & $52.6(41 / 78)$ \\
\hline Total in 1997 & $0.9(9 / 974)$ & $4.7(17 / 365)$ & $5.6(8 / 143)$ & $33.5(126 / 376)$ \\
\hline '98. Mar. & $0(0 / 3)$ & $0(0 / 18)$ & $0(0 / 3)$ & $0(0 / 18)$ \\
\hline Apr. & $0(0 / 38)$ & $0(0 / 587)$ & $0(0 / 38)$ & $1.4(8 / 587)$ \\
\hline May & $0(0 / 13)$ & $0.9(1 / 111)$ & $0(0 / 13)$ & $0.9(1 / 111)$ \\
\hline Jun. & $0(0 / 13)$ & $1.6(2 / 122)$ & $0(0 / 13)$ & $13.9(17 / 122)$ \\
\hline Jul. & $0(0 / 108)$ & $1.4(2 / 148)$ & $0(0 / 21)$ & $24.3(36 / 148)$ \\
\hline Total in 1998 & $0(0 / 175)$ & $0.5(5 / 986)$ & $0(0 / 88)$ & $6.3(62 / 986)$ \\
\hline '99. Mar. & $0(0 / 15)$ & $0(0 / 181)$ & $0(0 / 15)$ & $0(0 / 181)$ \\
\hline Apr. & $0(0 / 10)$ & $0(0 / 262)$ & $0(0 / 10)$ & $0(0 / 262)$ \\
\hline May & $0(0 / 5)$ & $0(0 / 39)$ & $0(0 / 5)$ & $0(0 / 39)$ \\
\hline Jun. & $0(0 / 10)$ & $6.8(5 / 74)$ & $0(0 / 10)$ & $41.9(31 / 74)$ \\
\hline Jul. & $0(0 / 7)$ & $10.6(7 / 66)$ & $14.3(1 / 7)$ & $56.1(37 / 66)$ \\
\hline Total in 1999 & $0(0 / 47)$ & $1.9(12 / 622)$ & $2.1(1 / 47)$ & $10.9(68 / 622)$ \\
\hline
\end{tabular}

spawning was $0.9 \%$ in 1997 , and $0 \%$ in 1998 and 1999. The values for ovary after spawning were $4.7 \%$ (1997), 0.5\% (1998) and 1.9\% (1999). From the receptaculum seminis, the total prevalence of PRDV before spawning was $5.6 \%$ in $1997,0 \%$ in 1998 and $2.1 \%$ in 1999 , whereas after spawning the values were $33.5,6.3$ and $10.9 \%$, respectively. Thus, PRDV was detected from the receptaculum seminis at higher rate after spawning than those before spawning and its prevalence increased rapidly from June on.

\section{Prevalence of PRDV in different spawning states}

Figure 1 shows the prevalence of PRDV from receptaculum seminis depending on the spawning state of broodstock after spawning. In 1997, the prevalence of PRDV in July and August were $44.1 \%$ and $61.9 \%$ in the group of complete spawning (Group 1), and these values were higher than those in the groups of partial spawning (Group 2) or non-spawning brooders (Group 3). In Group 1, these values in June and July in 1998 were $15.7 \%$ and $25.3 \%$, whereas those in 1999 were $64.7 \%$ and $90.7 \%$, respectively. Thus, brooders with complete spawning showed the highest prevalence of PRDV among 3 groups.

\section{Prevalence of PRDV in 3 groups with different induction periods}

The prevalence of PRDV in the receptaculum seminis after spawning was compared among the 3 groups with different induction periods (1-3 days) for spawning as shown in Fig. 2. In 1997, the prevalence of PRDV on the 3rd day post-spawning in July and August were $83.8 \%$ and $91.7 \%$, respectively. The values in June and July were $100 \%$ and $92.3 \%$ in 1998 , and $90.0 \%$ and $100 \%$ in 1999 .

\section{Discussion}

As reported previously, PRDV was detected at higher rates from the ovaries than from the hemolymph or stomach in wild-captured female broodstock (Mushiake et al., 1998). On the basis of these results, we had attempted to prevent PAV in seed production in 1997 by selection of PRDV-negative spawners based on the PCR detection of the virus from ovaries just before spawning. However, PAV occurred in post-larval juveniles obtained from PCR-negative brooders caught between July and August, in the rearing experiments at Kamiura Station of JASFA. In the present study, it became evident that the detection rate of PRDV from the receptaculum seminis of prawns after spawning was much higher than that from the ovaries before spawning as shown in Table 1. Based on these results, only eggs obtained from PCR-negative in the receptaculum seminis were supplied for rearing experiments in 1998 and 1999. As a result, PRDV was not detected from juveniles in any developmental stages up to P50 and no PAV infection occurred during the rearing experiments 


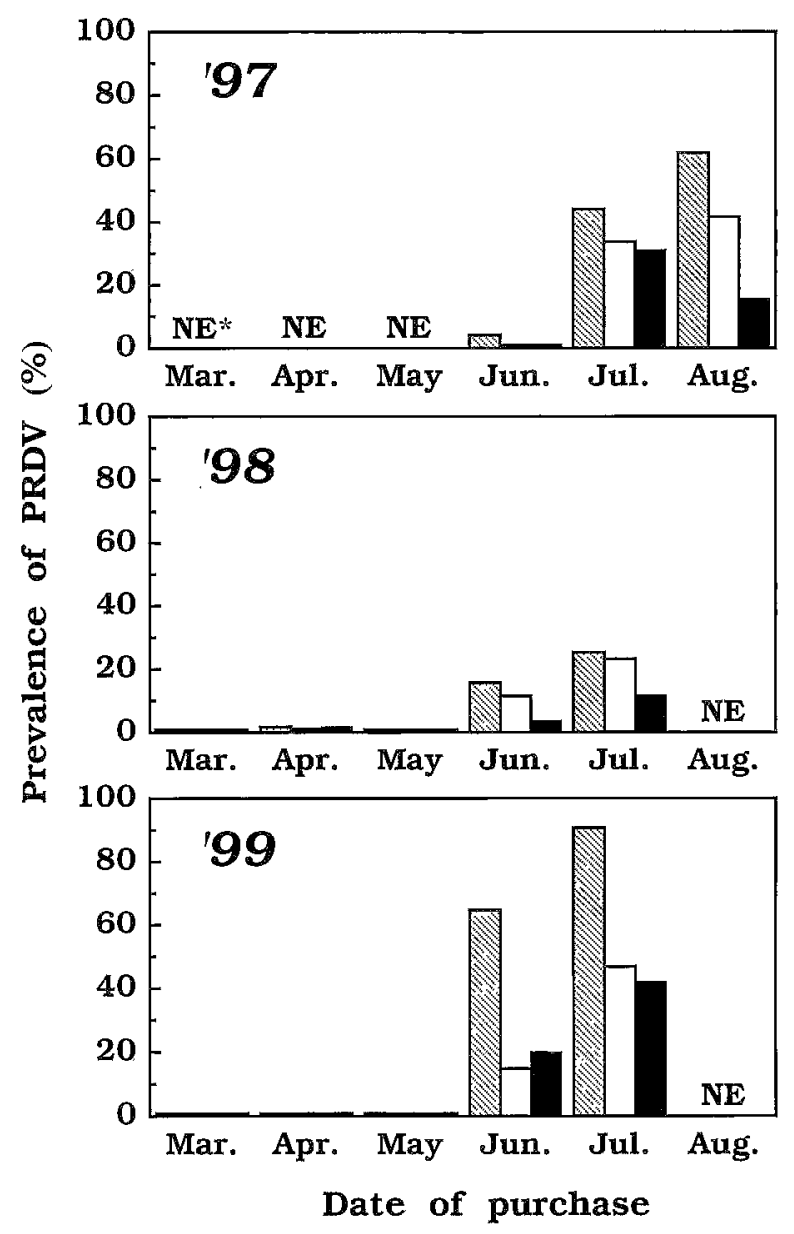

Fig. 1. Prevalence of PRDV in the receptaculum seminis of kuruma prawn spawners at different spawning states during 1997-1999.

* Not examined.

complete spawning, $\square$ partial spawning, non-spawning

carried out in these 2 years. Similarly, in large scale seed production $\left(200-2,500 \mathrm{~m}^{3}\right)$ of kuruma prawn at Shibushi Station of JASFA (Kagoshima Pref.), no PAV occurred in juveniles up to P40-P65 $(1998,1999)$ after adopted the same method of control. These results strongly indicate that the selection of eggs based on the PRDV detection from the receptaculum seminis of brooders after spawning is a practical way of controlling PAV in seed production.

The present study also demonstrated that the detection rate of PRDV in the receptaculum seminis was higher when the females completely spawned, especially in the females which required longer incubation period for spawning. This suggests that spawning stress is the critical factor to allow viral multiplication in broodstock. However, we cannot conclude whether the PRDV detected in receptaculum seminis originated from the sperm of the male or from some organs of the female. In P. monodon, Lo et al. (1997) reported that WSBV (white spot syndrome baculovirus) was highly

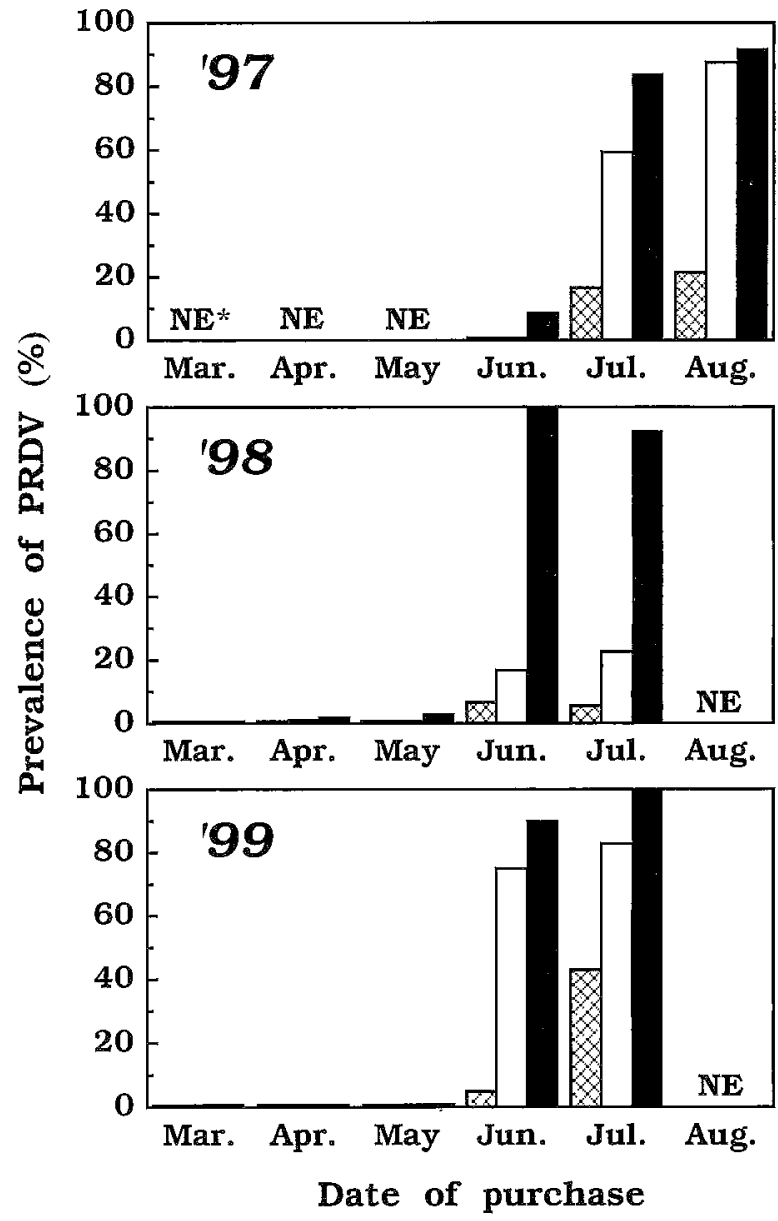

Fig. 2. Prevalence of PRDV in the receptaculum seminis of kuruma prawn spawners of 3 groups with different induction periods (1-3 days) for spawning during 1997-1999.

*Not examined.

1st day, $\square$ 2nd day, $\square$ 3rd day

detected in both male and female brooders, and that WSBV was present in the muscle and connective tissue of receptaculum seminis by in situ hybridization, but was absent in the sperm and epithelial cells of the organ. These results seem to indicate that the higher detection rate of WSBV from the receptaculum seminis in $P$. monodon was caused by the viral transmission from male to female during copulation. However, our previous report showed that the prevalence of PRDV in wildcaptured adult female kuruma prawns was higher than that in male prawns (Mushiake et al., 1998). Detailed information on the increase of PRDV in the receptaculum seminis of $P$. japonicus for the progress of spawning will be given by a study using in situ hybridization.

The increase in the detection rates of PRDV from receptaculum seminis or ovaries after spawning in kuruma prawns corresponds with the result of previous work on $P$. monodon (Lo et al., 1997). The increase in detection rate of PRDV in the receptaculum seminis is 
caused by the multiplication of the virus during the spawning, probably due to stresses from handling and spawning, or by the reduction in the amount of sperm, which will disturb PCR reaction with insufficient DNA extraction.

In $P$. monodon, it was suggested that infected egg cells are killed by WSBV before maturation (Lo et al., 1997), and that rinse or disinfection of the nauplii is one of the most effective way as a preventive measure of the disease in seed production (Lo and Kou, 1998). However, in $P$. japonicus, it was found that disinfection of the nauplii with povidone-iodine gave a serious damage to their survival (data not shown). Therefore, in the present study, eggs were disinfected with povidoneiodine ( $5 \mathrm{mg} / \mathrm{L}$ as active ingredient for $5 \mathrm{~min}$ ) in order to inactivate the virus that might attach to the surface of the eggs. The effectiveness of this method was not approved because PAV occurred in juveniles from the infected eggs in 1997.

The egg collection of kuruma prawn for seed production completely depends on wild-captured broodstocks in Japan. As shown in Table 1, the prevalence of PRDV increased rapidly from June. Therefore, it is also an effective measure for controlling PAV to use broodstocks caught before June for seed production. Trials of egg collection from artificially reared $P$. japonicus have been made, however, it has been pointed out that these eggs were of an inferior quality to those of wild-captured broodstock (Yano, 1987; Y. Miyajima, unpublished data). Therefore, at present, to use wild-captured kuruma prawn adults after segregation of PRDV-positive spawners is only the practical option for seed production of this species in Japan.

\section{Acknowledgements}

The authors are grateful to Drs. Kiyokuni Muroga and Toyohiko Nishizawa of Hiroshima University and Dr. Keiji Hirose of JASFA for their critical readings of the manuscript. We thank Messrs. Toru Furusawa, Shigeru Matsunaga and Younosuke Mizuta of JASFA for their encouragement and valuable suggestion in this study. Moreover we express our gratitude to Mrs. Keiko Enokiya, Yasumi Yoshioka and Ikuko Yamaji of Kamiura Station in the detection of PRDV by PCR.

\section{References}

Chou, H. Y., C. Y. Huang, C. H. Wang, H. C. Chiang and C. F. Lo (1995): Pathogenicity of a baculovirus infection causing white spot syndrome in cultured penaeid shrimp in Taiwan. Dis. Aquat. Org., 23, 165-173.

Inouye, K., K. Yamano, N. Ikeda, T. Kimura, H. Nakano, K. Momoyama, J. Kobayashi and S. Miyajima (1996): The penaeid rod-shaped DNA virus (PRDV), which causes penaeid acute viremia (PAV). Fish Pathol., 31, 39-45.

Kimura, T., K. Yamano, H. Nakano, K. Momoyama, M. Hiraoka and K. Inouye (1996): Detection of penaeid rod-shaped
DNA virus (PRDV) by PCR. Fish Pathol., 31, 93-98.

Lightner, D. V. (1996): A handbook of pathology and diagnostic procedures for diseases of penaeid shrimp. Special publication of the World Aquaculture Society, Baton Rouge, LA, (sections 1-7).

Lo, C. F., J. H. Leu, C. H. Ho, C. H. Chen, S. E. Peng, Y. T. Chen, C. M. Chou, P. Y. Yeh, C. J. Huang, H. Y. Chou, C. H. Wang and G. H. Kou (1996): Detection of baculovirus associated with white spot syndrome (WSBV) in penaeid shrimps using polymerase chain reaction. Dis. Aquat. Org., 25, 133-141.

Lo, C. F., C. H. Ho, C. H. Chen, K. F. Liu, Y. L. Chiu, P. Y. Yeh, S. E. Peng, H. C. Hsu, H. C. Liu, C. F. Chang, M. S. Su, C. H. Wang and G. H. Kou (1997): Detection and tissue tropism of white spot syndrome baculovirus (WSBV) in captured brooders of Penaeus monodon with a special emphasis on reproductive organs. Dis. Aquat. Org., 30, 53-72.

Lo, C. F. and G. H. Kou (1998): Virus-associated white spot syndrome of shrimp in Taiwan: A review. Fish Pathol., 33, 365-371.

Maeda, M., T. Itami, A. Furumoto, O. Hennig, T. Imamura, M. Kondo, I. Hirano, T. Aoki and Y. Takahashi (1998): Detection of penaeid rod-shaped DNA virus (PRDV) in wildcaught shrimp and other crustaceans. Fish Pathol., 33, 373-380.

Miyajima, Y. and A. Matsumoto (1996): Maturity classification using biopsy in pond-reared broodstock of kuruma prawn Penaeus japonicus and efficient egg removal. Saibai Giken, 25, 37-40. (In Japanese)

Momoyama, K., M. Hiraoka, K. Inouye, T. Kimura, H. Nakano and M. Yasui (1997): Mass mortalities in the production of juvenile greasyback shrimp, Metapenaeus ensis, caused by penaeid acute viremia (PAV). Fish Pathol., 32, 51-58.

Mushiake, K., M. Arimoto, J. Satoh and K. Mori (1998): Detection of PRDV from wild adult kuruma prawn. Fish Pathol., 33, 503-509.

Nakano, H., H. Koube, S. Umezawa, K. Momoyama, M. Hiraoka, K. Inouye and N. Oseko (1994): Mass mortalities of cultured kuruma shrimp, Penaeus japonicus, in Japan in 1993: Epizootiological survey and infection trials. Fish Pathol., 29, 135-139.

Peng, B., J. Ren, J. Shen, G. Zhou, H. Gu, Y. Shen, G. Zheng and Z. Gong (1995): The studies on baculovirus-caused disease of prawns (Penaeus chinensis) in Shanghai suburb. Chinese J. Virol., 11, 151-157.

Satoh, J., K. Mushiake, K. Mori, M. Arimoto, K. Imaizumi, T. Nishizawa and K. Muroga (1999): Occurrence of PAV (penaeid acute viremia) in seed production of kuruma prawn. Fish Pathol., 34, 33-38.

Takahashi, Y., T. Itami, M. Maeda, N. Suzuki, J. Kasornchandra, K. Supamattaya, R. Khongpradit, S. Boonyaratpalin, M. Kondo, K. Kawai, R. Kusuda, I. Hirono and T. Aoki (1996): Polymerase chain reaction (PCR) amplification of bacilliform virus (RV-PJ) DNA in Penaeus japonicus Bate and systemic ectodermal and mesodermal baculovirus (SEMBV) DNA in Penaeus monodon Fabricius. J. Fish Dis., 19, 399-403.

Wongteerasupaya, C., J. E. Vickers, S. Sriurairatana, G. L. Nash, A. Akarajamorn, V. Boonsaeng, S. Panyim, A. Tassanakajon, B. Withyachumnarnkul and T. W. Flegel (1995): A non-occluded, systemic baculovirus that occurs in cells of ectodermal and mesodermal origin and causes high mortality in the black tiger prawn Penaeus monodon. Dis. Aquat. Org., 21, 69-77.

Yano, I. (1987): Maturation of kuruma prawns Penaeus japonicus cultured in earthen ponds. NOAA Tech. Rep. NMFS, 47, 3-7. 